\title{
Papers
}

\section{Prospective investigation of transfusion transmitted infection in recipients of over 20000 units of blood}

\author{
Fiona A M Regan, Patricia Hewitt, John A J Barbara, Marcela Contreras on behalf of the current \\ TTI Study Group
}

\begin{abstract}
Objectives To follow up recipients of 20000 units of blood to identify any transmissions of infections through blood transfusion.

Design Follow up study of recipients of transfusion. Setting 22 hospitals in north London.

Participant Adult patients who had recently been transfused.

Main outcome measures Patients had further blood samples taken at 9 months that were tested for markers of hepatitis B and C and HIV and human T cell leukaemia/lymphoma virus type I or II (HTLV) infections. Recent infections were distinguished from pre-existing infections by comparison with blood samples taken before transfusion.

Results 9220 patients were recruited, and 5579 recipients of 21923 units of blood were followed up. No transfusion transmitted infections were identified. The incidence of transfusion transmitted infections was 0 in 21043 units (95\% confidence interval for risk 0 to 1 in 5706 recipients) for hepatitis B; 0 in 21800 units ( 0 to 1 in 5911 recipients) for hepatitis $\mathrm{C}$; 0 in 21923 units (0 to 1 in 5944 recipients) for HIV; and 0 in 21902 units (0 to 1 in 5939 recipients) for human $\mathrm{T}$ cell leukaemia/lymphoma virus. Three patients acquired hepatitis B during or after hospital admission but not through transfusion; 176 (3\%) had pre-existing hepatitis B infection. Sixteen $(0.29 \%)$ patients had hepatitis C, and five $(0.09 \%)$ had human $\mathrm{T}$ cell leukaemia/lymphoma virus.

Conclusions The current risk of transfusion transmitted infections in the United Kingdom is very small, though hospital acquired infections may arise from sources other than transfusion. A considerable proportion of patients have pre-existing infections.
\end{abstract}

\section{Introduction}

In recent years there has been increased public concern about the safety of blood transfusion with respect to transfusion transmitted infections. HIV-1, HIV-2, hepatitis B, hepatitis $\mathrm{C}$, and human $\mathrm{T}$ cell leukaemia/lymphoma virus are transmissible by transfusion and are associated with important clinical disease. Every effort is made to minimise the risk of disease transmission, and in the United Kingdom blood is collected from voluntary, unpaid donors after careful questioning and selection. All donations are screened for hepatitis B surface antigen and antibodies to HIV-1 and HIV-2, hepatitis C virus, and syphilis with assays of steadily increasing sensitivity. A theoretical possibility of transmission remains if the donor is in the "window period" of an infection (that is, infectious but has not developed detectable markers of infection) or if the donor is a "low level carrier," in whom the level of markers of chronic infection is below the sensitivity of currently used assays (for example, for hepatitis B surface antigen). In addition, rare strain variants of a virus may not be detectable by certain routine tests, and possibilities of technical or clerical errors in screening or quarantining blood components remain, although these are increasingly rare as automation and computerised information transfer improves.

Previously, estimates of the incidence of transfusion transmitted infection have relied on reported cases of infection, but these are often asymptomatic and even when obvious are underreported. A study in the United Kingdom before screening for anti-hepatitis C virus showed that the incidence of post-transfusion non-A, non-B hepatitis was $0.26 \% .{ }^{1}$ A study in the United States between 1985 and 1988 showed that transmission of HIV (and human T cell leukaemia/lymphoma virus) was possible from donations which had been screened for anti-HIV. ${ }^{2}$ There have been no corresponding UK data for transmission of infections, which is needed so that informed decisions regarding transfusion practice can be made by clinicians and patients. This will be particularly relevant if informed consent for transfusion is ever introduced in the United Kingdom.

This prospective study aimed to estimate directly the incidence of transfusion transmitted infections: hepatitis $\mathrm{B}$ and $\mathrm{C}$ and HIV, for which donated blood is tested, and also human $\mathrm{T}$ cell leukaemia/lymphoma virus, for which blood is not currently tested in the United Kingdom. At the start of the study in 1991 we planned to study recipients of 20000 units of blood; this was based on estimates of the residual risks of infections at that time. Current estimates of risk in the United States ${ }^{3}$ and the United Kingdom (Barbara J and Soldan K, personal communication, 1999), based on the incidence, prevalence, and window periods of infections in donors, indicate lower risks of infection, so that a prospective study following a large enough number of recipients to define precisely the risk of infections would not be feasible. Fol-

\author{
National Blood \\ Service, London \\ and South East \\ Zone, North \\ London Centre, \\ London NW9 5BG \\ Fiona A M Regan \\ research fellow \\ Patricia Hewitt \\ lead consultant in \\ transfusiom \\ microbiology \\ John A J Barbara \\ lead scientist in \\ transfusion \\ microbiology \\ Marcela Contreras \\ executive director \\ Correspondence to: \\ P Hewitt \\ patricia.hewitt@ \\ nbs.nhs.uk \\ BMJ 2000;320:403-6
}


Table 1 Testing of each patient's sample nine months after transfusion

\begin{tabular}{ll}
\hline Initial tests & Confirmatory tests* \\
\hline Hepatitis B virus & \\
\hline Hepatitis B surface antigen (EIA) & Hepatitis B surface antigen (EIA, neutralising) \\
\hline Anti-hepatitis B core (EIA) & Anti-hepatitis B core (RIA*) \\
\hline & Anti-hepatitis B surface (RIA*) \\
\hline Hepatitis C virus & \\
\hline Anti-hepatitis C virus (EIA) & Anti-hepatitis C virus (EIA) \\
\hline & Anti-hepatitis C virus RIBA-3 \\
\hline HIV & \\
\hline Anti-HIV 1 and 2 (EIA) & Anti-HIV (EIA, GPA, western blot) \\
\hline
\end{tabular}

Human T cell leukaemia/lymphoma virus

Anti-HTLV (GPA) Anti-HTLV (EIA, GPA, western blot)

*Performed at reference laboratory (department of virology, Royal Free and University College Medical School) according to standard protocols in use at time.

low up of recipients of even 20000 units of blood, however, would provide direct evidence of the level of safety, within defined limits, in the absence of screening for antibodies to hepatitis B core antigen and anti-human T cell leukaemia/lymphoma virus.

\section{Methods}

\section{Participants and samples}

Patients were recruited shortly after being transfused and were followed up nine months after transfusion. From 1 August to 31 May we recruited patients from 22 hospitals in the North West Thames area, after hospital ethical committee approval was obtained. Patients were eligible for enrolment if they had recently had a red cell transfusion and a serum sample was available from before transfusion, they were able to understand what was being asked, they were over 18 years old (for consent to testing), and their life expectancy was at least nine months. Immunosuppressed patients were excluded as were patients with pre-existing hepatitis B virus, hepatitis $\mathrm{C}$ virus, $\mathrm{HIV}$, or human $\mathrm{T}$ cell leukaemia/lymphoma virus infection.

Initially, a team member explained the study and the tests entailed. Participation was voluntary, and patients were free to withdraw at any time. Written consent was obtained, and a pretransfusion serum sample was stored frozen at $-20^{\circ} \mathrm{C}$. The identity of the red cells transfused was documented. The study assessed the infectious risk only of red cells, though we also estimated the numbers of other blood components (fresh frozen plasma, platelets, cryoprecipitate) transfused, by extrapolation from known data for 100 patients from each of four hospitals.

Nine months after transfusion each patient was counselled, and, from those still willing to participate,

Table 2 Testing of sample from donor at least six months after possible transmission of infection

\begin{tabular}{llc}
$\begin{array}{l}\text { Tests on donor's } \\
\text { subsequent donation }\end{array}$ & Interpretation of result & $\begin{array}{c}\text { No of } \\
\text { donors }\end{array}$ \\
\hline Hepatitis B virus & & 230 \\
\hline $\begin{array}{l}\text { Anti-hepatitis B core } \\
\text { (Abbott IMx) }\end{array}$ & If negative, donor excluded as source of infection & 1 \\
\hline & $\begin{array}{l}\text { If positive, sample tested for virus DNA by polymerase chain } \\
\text { reaction and for anti-hepatitis B surface (as negative for DNA } \\
\text { virus and positive for anti-hepatitis B surface this was donor } \\
\text { excluded) }\end{array}$ & \\
\hline $\begin{array}{l}\text { Hepatitis C virus } \\
\begin{array}{l}\text { Anti-hepatitis C virus } \\
\text { (ElA-Pasteur) }\end{array}\end{array}$ & If negative, donor excluded & 36 \\
\hline
\end{tabular}

we obtained written consent for testing and a $20 \mathrm{ml}$ sample of blood. Serum was separated within 12 hours and stored at $-20^{\circ} \mathrm{C}$. To complete the study on time the last 940 patients were followed up at six rather than nine months after transfusion as tests with enhanced sensitivity became available. ${ }^{4}$

\section{Microbiological testing}

Post-transfusion samples were tested in duplicate within a week of collection by using assays approved nationally for blood donation screening (table 1). Samples were also tested for anti-hepatitis B core antigen (Wellcozyme) and by gel particle agglutination (GPA) for anti-human $\mathrm{T}$ cell leukaemia/lymphoma virus (Fuji). Repeatedly reactive samples underwent confirmatory testing (fig 1 ). If the results were positive the pretransfusion sample was tested for pre-existing infection. In the absence of pre-existing infection or if a pretransfusion sample was not available, a further sample was taken to exclude identification errors, then donors of all transfused components were tested to identify a potential source of infection. Furthermore, "window period" transmission was excluded by testing a sample taken from the donor at least six months later (table 2). If none of the tested donors yielded positive

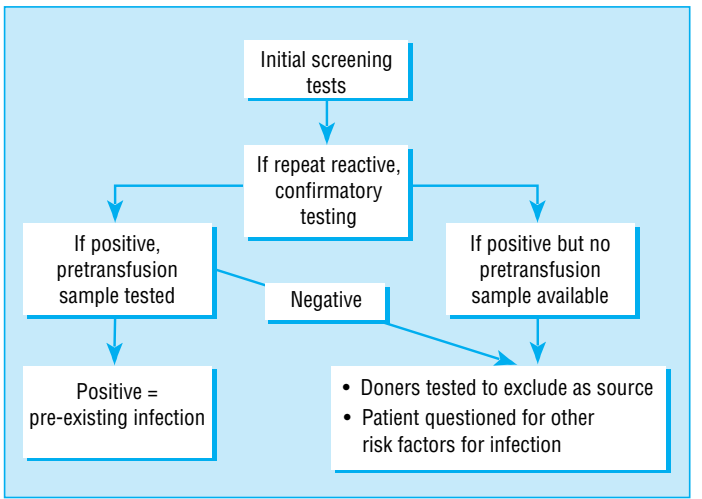

Fig 1 Testing of patients' samples nine months after transfusion

results, transfusion was excluded as a source of infection and the patient was questioned about other risk factors for infection. Patients were informed confidentially of test results.

When we calculated the risk of infection transmitted by transfusion, units received by patients with preexisting infections were discounted.

\section{Results}

We recruited 9220 patients (fig 2). Of these, 3641 $(39.4 \%)$ were withdrawn before follow up, either because they died (657), they were untraceable (250), or were too ill to participate (2734). We successfully followed up 5579 (60.5\%; 3000 women and 2579 men). The mean (range) age was 67 (16-96) years, and in total they received 21923 units of red cells (mean (range) 3.9 (1 to 98 ) units per patient). This represented about $10 \%$ of blood issued to participating hospitals during the period. This low proportion reflects the strict exclusion criteria for patients, particularly a life expectancy less than nine months. The mean (range) interval between transfusion and follow up sample was 10.7 (range 6-50) months. 




Fig 2 Outcome for patients recruited into study

Table 3 Patients with markers of hepatitis B infection present only in post-transfusion samples

\begin{tabular}{lccc} 
Post-transfusion* markers & Patient 1 & Patient 2 & Patient 3 \\
\hline Anti-B core & + & + & + \\
\hline Surface antigen & - & - & + \\
\hline Anti-B surface $(\mathrm{mlU} / \mathrm{ml})$ & 250 & 120 & -
\end{tabular}

*Pre-transfusion samples were negative for all markers of hepatitis $B$ virus. $+=$ positive.

$-=$ negative.

We did not identify any transfusion transmitted infections. We calculated the risk of transmission through blood as 0 in 21043 units of red cells for hepatitis B virus (95\% confidence interval of risk 0 to 1 in 5706 recipients); 0 in 21800 units for hepatitis $\mathrm{C}$ virus ( 0 to 1 in 5911 recipients); 0 in 21923 units for HIV (0 to 1 in 5944 recipients); and 0 in 21902 units for human T cell leukaemia/lymphoma virus ( 0 to 1 in 5939 recipients). Although the results are based on the number of red cells received, we estimated that patients would also have received fresh frozen plasma from 1630 donors, platelets from 3819 donors, and cryoprecipitate from 279 donors. This constitutes an additional 5728 donation exposures. An overall donation exposure of 27000 represents about 26000 individual donors (Gay N, personal communication, 1998).

Samples from three patients whose pretransfusion samples had yielded negative results showed markers of hepatitis B virus infection, indicating acquisition during or after admission to hospital (table 3). None of the relevant donors showed evidence of hepatitis B virus, and we could not identify any risk factors in patients other than their hospital treatment. Many patients had pre-existing infections, of which they were usually unaware (fig 2).

\section{Discussion}

The study population represented most of those patients from general medical and most surgical specialties who had received a transfusion and were not confused. For patients who died during the study, death due to infection with hepatitis $\mathrm{C}$ virus, HIV, or human T cell leukaemia/lymphoma virus would be unlikely within the follow up period, and hepatitis B virus infection would probably have been reported to us.

No transmitted infections were found after transfusion of 21923 units of red cells, and inclusion of exposures to other components resulted in an even smaller calculated risk of infection. Before this study, UK estimates of transfusion transmitted hepatitis B and C virus were 1 in 20000 and 1 in 13000 units, ${ }^{5}$ respectively, compared with 1 in 200000 and 1 in 3300 in the United States. ${ }^{6}$ Recent UK estimates suggest the risk for hepatitis B virus is 1 in 50000 to 170000 ; for hepatitis C virus is < 1 in 200000 ; and for $\mathrm{HIV}$ is $<1$ in 2 million units (Barbara J and Soldan K, personal communication,1999). Current US estimates are 1 in 63000,1 in 103 000, and 1 in 493000 , respectively. ${ }^{3}$ In Canada, there was no transmission of hepatitis B virus to 4588 patients and four to six transmissions of hepatitis $\mathrm{C}$ virus per 10000 units transfused at introduction of "first generation" screening for antibodies to hepatitis $\mathrm{C}$ virus. ${ }^{7}$

This study provides direct data on the lack of transfusion transmission of HIV, hepatitis B and C virus, and human $\mathrm{T}$ cell leukaemia/lymphoma virus in the United Kingdom. Elsewhere, donations are tested for antibodies to hepatitis B core antigen, ${ }^{8}$ which can detect infectious donors undetectable by tests for hepatitis B surface antigen. ${ }^{9}$ In the United States, testing for antibody to hepatitis B core antigen may prevent $33 \%$ to $50 \%$ of cases of hepatitis B potentially transmissible from donors who test negative for hepatitis B surface antigen. ${ }^{10}$ In the United Kingdom, the potential benefits of routine testing for antibodies to hepatitis B core antigen are considered not to outweigh the disadvantages (such as uncertainties in confirmation of infection and wastage of falsely positive units $\left.{ }^{11}\right)$.

The United States introduced HIV p24 antigen testing to reduce the HIV "window period" amid concerns that donors might seek a superior test of HIV status, unavailable outside blood centres. ${ }^{12}$ The gain, however, is far less than projected (Holland P, personal communication, 1997). Before anti-human $\mathrm{T}$ cell leukaemia/lymphoma virus testing of donors in the United States, risk of transmission was 1 in 4192 units transfused. ${ }^{2}$ Donated blood in the United Kingdom is not currently tested for human $\mathrm{T}$ cell leukaemia/ lymphoma virus. The prevalence of human $\mathrm{T}$ cell leukaemia/lymphoma virus among donors in north

\section{Table 4 Details of actual assays used}

\begin{tabular}{|c|c|c|}
\hline Initial tests & Manufacturer of initial test & Manufacturer of confirmatory tests \\
\hline \multicolumn{3}{|l|}{ Hepatitis B virus } \\
\hline B surface antigen (EIA) & $\begin{array}{l}\text { Bioelisa (Launch) (March 91-June 93) } \\
\text { Organon Hepanostika (June 93-June } \\
\text { 94) Murex (June 94-Dec 96) }\end{array}$ & Pasteur, GEIS \\
\hline Anti-B core (EIA) & Wellcozyme & Wellcozyme, Abbott IMx \\
\hline Anti-B surface & - & Wellcozyme, Abbott IMx \\
\hline \multicolumn{3}{|l|}{ Hepatitis C virus } \\
\hline Anti-C (EIA) & $\begin{array}{l}\text { Ortho II (Sept 91-May 93) Murex (May } \\
\text { 93-June 93) Ortho III (June 93-Aug } \\
\text { 93) Murex (Aug 93-Aug 95) Pasteur } \\
\text { (Aug 95-Dec 96) }\end{array}$ & - \\
\hline Anti-C virus (EIA) & - & Ortho, Sanofi \\
\hline Anti-C virus RIBA-3 & - & Chiron \\
\hline \multicolumn{3}{|l|}{ HIV } \\
\hline Anti-HIV 1+2 (EIA) & Wellcozyme & - \\
\hline Anti-HIV & - & Immunometric, GPA, western blot \\
\hline \multicolumn{3}{|c|}{ Human T cell leukaemia/lymphoma virus } \\
\hline Anti-HTLV (GPA) & Fuji & - \\
\hline Anti-HTLV & - & Select antiglobulin \\
\hline
\end{tabular}




\section{What is already known on this topic}

Every effort is made to minimise the risk of transfusion transmitted infection, but a theoretical possibility of transmission remains

Previously, estimates of the frequency of transfusion transmitted infection have relied on reported cases of infection, but these are often underreported

\section{What this paper adds}

This prospective study directly estimated the incidence of transfusion transmitted infections-hepatitis B and C and HIV-for which donated blood is tested, and also human $\mathrm{T}$ cell leukaemia/lymphoma virus, for which blood is not currently tested in the United Kingdom

Direct data are provided on the safety of the blood supply with regard to these infections and indicate the minimum level of safety of transfusion in the United Kingdom

Hospital acquired infections are more likely to arise from sources other than transfusion, as transmission by this route has become so rare

London was 1 in $19344^{13}$ but in Leeds was $<1$ in $80000 .{ }^{14}$ Our finding of no transmissions from 21000 units transfused was therefore not unexpected.

Three patients had markers for hepatitis B virus at follow up but their pretransfusion samples yielded negative results. If we can assume that the samples were correctly identified, the patients must have acquired the virus between transfusion and follow up as donors of all components transfused were excluded and all three recipients identified no other risk for hepatitis B virus. These patients probably acquired the virus during their stay in hospital but not through transfusion of the units recorded in the hospital records. Giving the wrong blood to patients is a known hazard of transfusion ${ }^{15}$; this cannot be excluded, although it is unlikely. Transmission of hepatitis B virus ${ }^{16}{ }^{17}$ and hepatitis C virus $^{18}$ to patients from healthcare workers and other patients $^{19}$ has been reported; transmission through contaminated equipment could also occur. The patients underwent surgery in different hospitals and no sources of infection were identified. Two patients underwent gastrointestinal surgery and the third had coronary artery bypass graft surgery.

In conclusion, patients and clinicians can now make decisions about transfusions on the basis of the study finding that directly assessed current risks of known transfusion transmitted infections in the United Kingdom are very small, though the possibility of new or unrecognised agents always remains. Hospital acquired infections are more likely to arise from sources other than transfusion as transmission by this route has become so rare. Clinicians must remain alert for infections after transfusion but should also consider routes of such infections other than transfusion.

The TTI Study Group comprises Mhairi Bailey, Dr David Howell, Julia McCartney, Anna Nolan, Annette Rochford, Beverley Vincent, Fiona Regan, Patricia Hewitt, John Barbara, and
Marcela Contreras. Susan Kilbane, Kellie Lawlor, Amanda Robotham were the administrative assistants for the study team; Dr Mary Brennan, Dr Therese Callaghan, Dr Gillian Century, Dr Joan Heyse-Moore, Dr Edith LeCoeur, Dr Diana Simons, Cindy Mooring, and Eleanor Dukes are previous members of the clinical team.

We are grateful to the following participating hospitals and NHS Trusts, particularly staff of transfusion departments and ward nursing staff for their cooperation in recruiting patients into the study: Ashford (Middlesex), Barnet General, Royal Brompton, Central Middlesex, Charing Cross, Chelsea and Westminster, Ealing, Edgware, Hemel Hempstead and St Albans, Hertford County (East Herts), Hillingdon, Lister (North Herts), Mount Vernon and Watford, Northwick Park and St Marks, Q E II (East Herts), Royal National Orthopaedic (Stanmore), St Mary's, St Vincent's, West Middlesex University, and Whittington. We thank Professor Richard Tedder, professor of medical virology, department of virology, Royal Free and University College Medical School, and Kate Soldan, NBA/ CDSC Surveillance Officer, Central Public Health Laboratory, Colindale, for their expert advice. We are also indebted to all the general practitioners who assisted with the follow up of patients who lived outside the area.

Contributors: FAMR was responsible for execution of the study, accrual and analysis of data, regular review, and analysis of the paper. $\mathrm{PH}$ was responsible for overall design and execution of the study, regular review, and analysis and corrections in the paper. JAJB was responsible for overall study design, expert microbiological advice, test results, regular review of execution of the study, and analysis of the paper. $\mathrm{MC}$ was responsible for overall study design, obtaining funding, regular review of execution of the study, and analysis of the paper. MC is the guarantor. Funding: North West Thames Regional Health Authority.

Competing interests: None declared.

1 Contreras M, Barbara JAJ, Anderson CC, Ranasinghe E, Moore C, Brennan MT, et al. Low incidence of non-A, non-B post transfusion hepatitis in London confirmed by hepatitis C virus serology. Lancet 1991;30:753-7.

2 Cohen ND, Munoz A, Reitz BA, Ness PK, Frazier OH, Yawn DH, et al. Transmission of retroviruses by transfusion of screened blood in patients undergoing cardiac surgery. N Engl J Med 1989;320:1172-6.

3 Schreiber GB, Busch MP, Kleinman SH, Korelitz IJ. The risk of transfusion-transmitted viral infections. $N$ Engl J Med 1996;334:1685-90.

4 Alter $\mathrm{HJ}$.New kit on the block: evaluation of second generation assays for detection of antibody to the hepatitis $\mathrm{C}$ virus [editorial; comment]. Hepatology 1992;15:350-3

5 Contreras M, Barbara J. Transfusion transmitted infections and their impact on virology. Current Med Lit (RSM) Virol 1993;4:67-72.

6 Dodd RY. The risk of transfusion-transmitted infection. $N$ Engl J Med 1992;327:419-20.

7 Blajchman MA, Bull SB, Feinman SV. Post-transfusion hepatitis: impact of non-A, non-B hepatitis surrogate tests. Lancet 1995;345:21-5.

8 Infectious disease testing for blood transfusions. NIH Consensus Statement $1995 ; 13: 1-27$

9 Kojima M, Shimizu M, Tsuchimochi T, Koyasu M, Tanaka T, Okamoto H, et al. Post-transfusion fulminant hepatitis B associated with pre core-defective HBV mutants. Vox Sang 1991;60:34-9.

10 Mosely JW, Stevens CE, Aach RD, Hollinger FB, Mimms LT, Solomon LR, et al. Donor screening for antibody to hepatitis B core antigen and hepatitis B virus infection in transfusion recipients. Transfusion 1995;35:5-12.

11 Allain JP, Reeves I, Kitchen AD, Wenham D, Williamson LM. Feasibility and usefulness of an efficient anti-HBc screening programme in blood donors. Trans Med 1995;5:259-65

12 Korelitz JJ, Busch MP, Williams AE. Antigen testing for human immunodeficiency virus (HIV) and the magnet effect: will the benefit of a new HIV test be offset by the numbers of higher-risk, test-seeking donors attracted to blood centres? Transfusion 1996;36:203-8.

13 Brennan M, Runganga J, Barbara JAJ, Contreras M, Tedder RS, Garson J, et al. Prevalence of antibodies to human T cell leukaemia/lymphoma virus in blood donors in north London. BMJ 1993;307:1235-9.

14 Flanagan P, McAlpine L, Ramskill SJ. Evaluation of a combined HIV-1/2 and HTLV-I/II assay for screening blood donors. Vox Sang $1995 ; 68: 220-4$.

15 Williamson LM, Lowe S, Love EM, Cohen H, Soldan K, McClelland DBL, et al. SHOT annual report 1996-1997. Manchester: SHOT Office, Manchester Blood Centre, 1998.

16 Harpaz R, Von Seidlein L, Averhoff F, Tormey MP, Sinha SD, Kotsopoulou K, et al. Transmission of hepatitis B virus to multiple patients from a surgeon without evidence of inadequate infection control. $N$ Engl J Med 1996:334:549-54.

17 Bell DM, Shapiro CN, Gooch BF. Preventing HIV transmission to patients during invasive procedures. J Public Health Dent 1993;53:170-3.

18 Esteban JI, Gomez J, Martell M, Cabot B, Quer J, Camps J, et al. Transmission of hepatitis C virus by a cardiac surgeon. $N$ Engl J Med 1996;334:555-60.

19 Allander T, Gruber A, Naghavi M, Beyene A, Söderström T, Björkholm M, et al. Frequent patient-to-patient transmission of hepatitis $\mathrm{C}$ virus in a haematology ward. Lancet 1995;345:603-7.

(Accepted 29 November 1999) 